UDC 524.572

\title{
Peculiarities of Usage Diamond-Like Carbon Films as Antireflection Coating
}

D. Zelinskyif , ORCID 0000-0002-8617-6562

National Technical University of Ukraine "Igor Sikorsky Kyiv Polytechnic Institute"

Kyiv, Ukraine

V. Horokhov, Researcher, ORCID 0000-0002-5609-6916

V. Bakul Institute for Superhard Materials of the National Academy of Sciences of Ukraine

Kyiv, Ukraine

O. Kondratenko, PhD, ORCID 0000-0003-1948-4431

V. Ye. Lashkaryov Institute of Semiconductor Physics, NAS of Ukraine

Kyiv, Ukraine

L. Shmyrovas, PhD Assoc.Prof., ORCID 0000-0001-5497-4140

National Technical University of Ukraine "Igor Sikorsky Kyiv Polytechnic Institute"

Kyiv, Ukraine

T. Semikinas , PhD Senior Research Fellow, ORCID 0000-0002-6182-4703

V. Ye. Lashkaryov Institute of Semiconductor Physics, NAS of Ukraine

Kyiv, Ukraine

\begin{abstract}
The series of three diamond-like carbon films was fabricated using Plasma - Enhanced Chemical Vapor Deposition setup designed for deposition of amorphous silicon films. The deposited films were analyzed by Spectroscopic ellipsometer Semilab SE-2000 in terms of optical properties. All the measurements were analyzed and modeled by the Fresnel equations. Three parameters were identified: refractive index, extinction index, and thickness. The range of these values indicates that the films can be used as antireflection coatings. The obtained values for $n, k$, and $d$ are located in ranges: for $\mathrm{n}-1.484$ and 1621 , for $\mathrm{k}-\mathbf{0 . 3 4 5}$ and 0.062 , and for $d-136.20$ and 74.66 .
\end{abstract}

Keywords - DLC film; PECVD method; spectroscopic ellipsometry; antireflection coatings; refractive index.

\section{INTRODUCTION}

Silicon solar cells, ultraviolet radiation detectors and germanium exterior windows of night vision devices are widely used in optoelectronics. However, despite the very low absorption in the infrared spectral range, when using optical components of such materials, large losses of energy of light flux occur due to the considerable Fresnel reflectance in the whole UV and IR range. These losses can be reduced by applying single-layer quarter-wave luminescent diamond coatings. The main problem with the deposition of a-C based optical coatings films is to ensure their uniformity over a large area, proper adhesion contact with the substrate, minimal content of x extraneous impurities, achievement and stable reproduction of a certain structure, which will provide the required optical characteristics.
It is known that films a-C:H with a refractive index of more than 2.0 differ in relative transparency in the IR spectral region and are a promising optical material, because of combining properties such as: chemical resistance and mechanical strength. So, for example, a single-layer coating based on a-C: $H$ with $n=2$ is an ideal antireflection coating for optical elements made of germanium with $\mathrm{n}=4$ [1]-[6].

The method of deposition of carbon films from plasma stimulated by the HF-discharge satisfies the above requirements of the antireflection interference structures is at the same time functionally protective with the outer diamond-like layer. Amorphous hydrogenated carbon films $(\mathrm{a}-\mathrm{C}: \mathrm{H})$ were precipitated in a plasma-chemical reactor with a capacitive RF discharge, equal-sized planeparallel disk mixtures. The design of the installation provided the possibility of variation of the chemical composition and structure of the deposited films and accordingly 
facilitated the obtaining of a coating of a given composition and structure within the possible limits of their change.

The developed technology of obtaining diamond-like carbon films made it possible to minimize defects, uncontrolled impurities, the magnitude of internal stresses and at the same time ensure the uniformity of the physical properties of the film over the surface of the substrate. The technological process is quite energy efficient. To study the possibility of using the obtained films as an antireflection coating, it is necessary to measure and calculate optical parameters, such as the refractive index and extinction coefficient. Refractive index $\mathrm{n}$, extinction coefficient $\mathrm{k}$, and thickness $\mathrm{d}$ were determined using the method of multi-angle ellipsometry at the wavelength $632.8 \mathrm{~nm}$.

\section{EXPERIMENT}

The DLC films were deposited by plasma-chemical reactor for the deposition of amorphous hydrogenated carbon films from HF-discharge hydrocarbon plasma (PECVD method) which is shown on the Fig. 1, Fig. 2 and Fig. 3 and parameters shown in the Table 1.

One of the key features of PECVD is that a variety of substrates can be used because the substrate temperature is kept low, typically below $250^{\circ} \mathrm{C}$. Deposition can occur at a low temperature because as indicated by the name, a plasma or glow discharge is used to generate the reactive species necessary for film growth. A plasma is a volume of gas consisting of a high density of charge carriers (ions and electrons). The high density of charge carriers in plasmas, give it a number of distinguishing properties from non-ionized gases, and thus plasmas are often referred to as the fourth state of matter. In PECVD, a plasma is generated by an external electric field being applied to a volume of low pressure gas, typically less than 1 Torr. Before the electric field is applied, the volume of gas has a very low density of charge carriers, created by cosmic radiation.

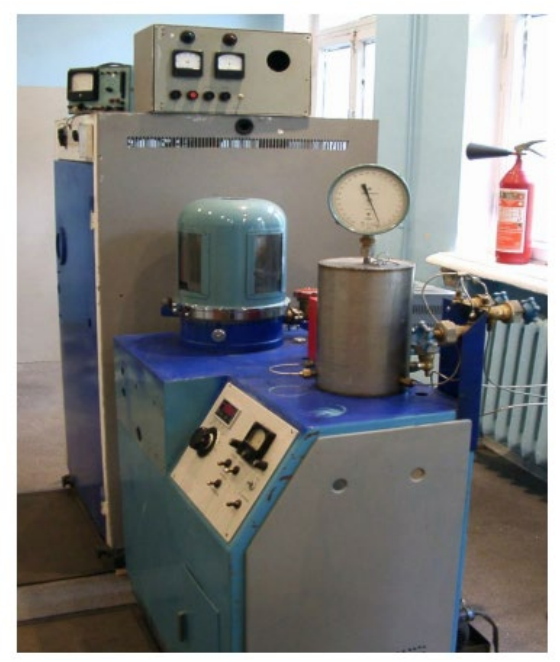

Fig. 1 General view of the plasma-chemical installation for the deposition of a-C:H films.
TABLE 1 DEPOSITION PARAMETERS

\begin{tabular}{|l|l|l|}
\hline Sample number & \multicolumn{1}{|c|}{$\begin{array}{c}\text { Deposition time, } \\
\text { min }\end{array}$} & Bias Voltage, V \\
\hline 1 & 12 & -100 \\
\hline 2 & 6 & -200 \\
\hline 3 & 4 & -250 \\
\hline
\end{tabular}

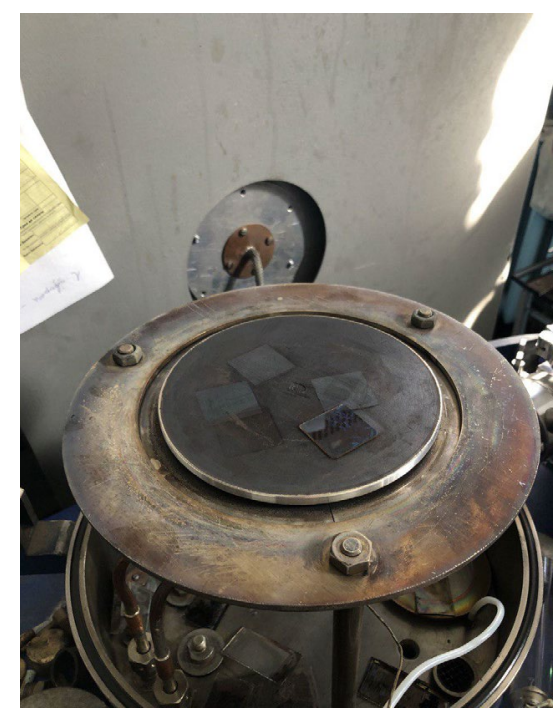

Fig. 2 View of the reaction chamber with a sample on the substrate.

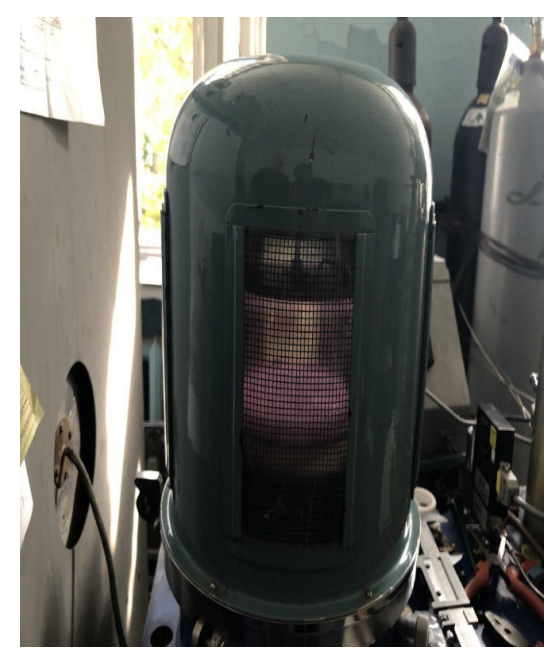

Fig. 3 General view of the vacuum chamber.

Once the field is applied, the charge carriers that are present accelerate and collide with neutral molecules (neutrals) in the gas. Through these collusions, energy is transferred from the energetic charge carriers to the neutrals causing ionization of the neutrals thus generating more charge carriers.

Energetic carriers also collide with electrodes and walls of the chamber causing ejection of new carriers into the gas. As charge density builds in the chamber, the rate of recombination of charge increases. The recombination of charge carriers occurs as electrons and ions in the plasma recombine with each other or are lost due 
to collisions with the walls of the chamber. In time, a steady-state is reached between the generation of newcharge carriers and the recombination of existing charge carriers. To control the deposition processes of carbon coatings and obtain reproducible results, it is necessary to measure the magnitude of the incident and reflected RF power or other directly related parameter. This parameter is the negative potential of the RF electrode. This bias voltage is caused by a significant difference in the velocities of ions and electrons. Controlling its magnitude directly allows you to estimate the average value of electron energy in a plasma discharge.

This not only achieves good reproducibility of technological results, but also realizes the ability to perform comparative assessments of the physical properties of carbon coatings obtained at other installations. Adjustment of the RF power, which allows for a possible variation of the displacement voltage in the range from -50 to $-700 \mathrm{~V}$. Excess values of the displacement voltage above $700 \mathrm{~V}$ is impractical. This is due both to the considerable resistive heating of the plasma chemical reactor and to the fact that experimentally established the fact that the sputtering processes in this case prevail over the processes of film coating formation of ions and radicals. The essence of the ellipsometric measurement method is to study the change in the state of polarization of a light beam as a result of its reflection from the studied object, what is presented on the Fig. 4.

The studies were carried out on a-C:H films deposited on glass substrates of acetylene vapor and hydrogen at ambient temperature. The ratio of the amplitudes $p$ and $\mathrm{s}$ of the components of the incident light beam and the phase shift between them were measured using a spectroscopic ellipsometer Semilab SE-2000 with radiation incidence angles of $50^{\circ}, 55^{\circ}, 60^{\circ}, 65^{\circ}$, and $70^{\circ}$. Further, according to the model of a homogeneous isotropic film on a glass substrate with known optical constants $(\mathrm{ns}=1.457, \mathrm{ks}=0)$, were selected unknown parameters $\mathrm{n}, \mathrm{k}$ and $\mathrm{d}$ within given limits until established the minimum difference between the calculated and measured values of the shift phases and ratios of amplitudes of $\mathrm{p}$ and $\mathrm{s}$ components. Found values were fixed as the determined optical constants (Fig. 2 and Fig. 3) and thickness films. The measured values of ellipsometric angles $\psi$ and $\Delta$, the calculated values in the model are shown by solid lines.

The coincidence of the lines with the measurement results (dots) indicates that the obtained data on the values of $\mathrm{n}, \mathrm{k}$, and $\mathrm{d}$ are correct. That the obtained low value for the refractive index in the range $1.484-1.623$ coincides with the data from [7]-[9]. It is shown in the work that a-C: $\mathrm{H}$ layers transparent in the visible spectral region and having low refractive indices can be used to form a homogeneous orientation of liquid crystals.

The ellipsometric parameters $\Delta$ and $\psi$ are related by the basic equation [10]:

$$
\left(\frac{\varepsilon_{p}^{\text {out }}}{\varepsilon_{S}^{\text {out }}}\right)=\left(\begin{array}{cc}
\tilde{r}_{p} & 0 \\
0 & \tilde{r}_{e}
\end{array}\right)\left(\frac{\varepsilon_{p}^{\text {in }}}{\varepsilon_{p}^{\text {in }}}\right)
$$

$$
\begin{gathered}
\frac{E_{p}^{\text {out }} / E_{p}^{\text {in }}}{E_{s}^{\text {out }} / E_{s}^{\text {in }}}=\frac{\tilde{r}_{p}}{\tilde{r}_{s}}=\frac{\left|r_{p}\right|}{\left|r_{s}\right|} e^{i\left(\delta_{p}-\delta_{s}\right)}=\tan (\psi) e^{i \Delta} \\
\tan (\psi)=\frac{\left|r_{p}\right|}{\left|r_{s}\right|} \\
\Delta=\delta_{p}-\delta_{s}
\end{gathered}
$$

where $r_{p}$ and $r_{s}$ are the total complex amplitude reflection coefficients for $\mathrm{p}$ - and s- polarizations. Thus, $\tan (\psi)$ is the ratio of amplitudes, and $\Delta$ is the phase difference of the components of the reflected light. Since the ratio of two quantities is measured, and not their absolute value, the result is not affected by a change in intensity light source and air absorption.

Ellipsometry is not a direct measurement method. To get the values optical constants of the film ( $\mathrm{n}$ and $\mathrm{k}$ ), it is necessary to use a model including initial and boundary values of the desired parameters. All the DLC films were measured by spectroscopic ellipsometer Semilab SE2000. Brewster's angle (2-0) is determined by the material refractive index, which allowed to determine the refractive index during the measurements.

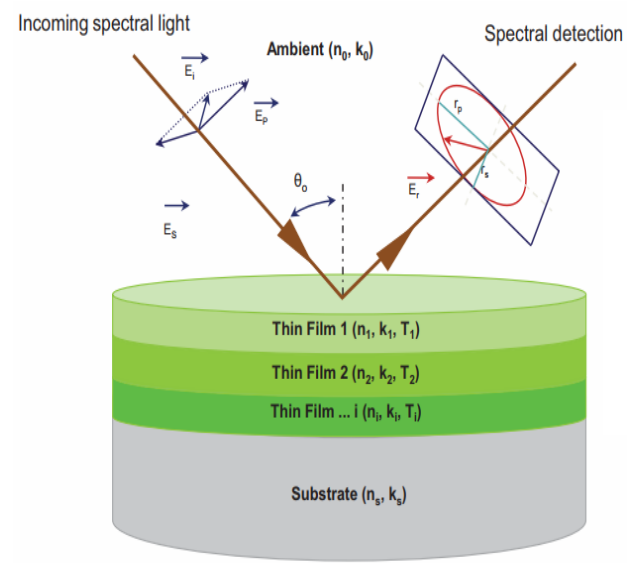

Fig. 4 Scheme of changes in the polarization of incident light in interaction with a reflective surface.

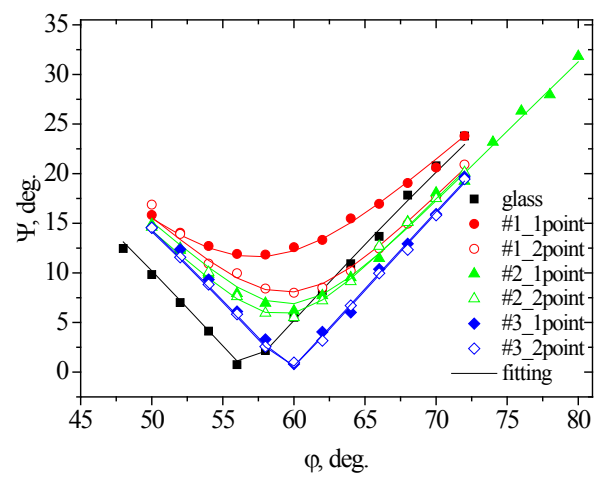

Fig. 5 Ellipsometric angles range 


\section{CONCLUSION}

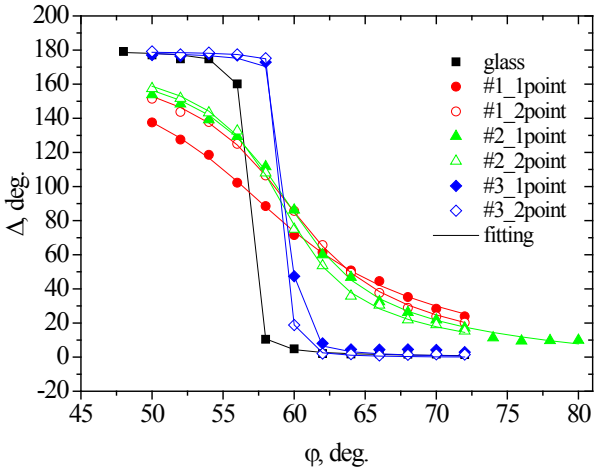

Fig. 6 Ellipsometric angles range.

TABLE 2 PARAMETERS N, K, D.

\begin{tabular}{|l|l|l|l|l|}
\hline $\begin{array}{c}\text { Sample } \\
\text { number }\end{array}$ & Point & $\mathbf{n}$ & $\mathbf{k}$ & $\mathbf{d}, \mathbf{n m}$ \\
\hline \multirow{2}{*}{1} & 1 & 1.484 & 0.345 & 136.20 \\
\cline { 2 - 5 } & 2 & 1.573 & 0.246 & 108.12 \\
\hline \multirow{2}{*}{2} & 1 & 1.605 & 0.196 & 116.00 \\
\cline { 2 - 5 } & 2 & 1.601 & 0.151 & 122.00 \\
\hline \multirow{3}{*}{3} & 1 & 1.623 & 0.072 & 73.40 \\
\cline { 2 - 5 } & 2 & 1.621 & 0.062 & 74.66 \\
\hline
\end{tabular}

$$
\Theta=\arctan (n)
$$

The results are presented in the Table 2, Fig. 5 and Fig. 6.

All the measurements were analyzed and modeled by the Fresnel equations. Three parameters were identified: refractive index, extinction index, and thickness as presented in Table 2

Such measurements are possible to determine the properties of nanometer layers and substrates in structures with various combinations of absorbing and lowabsorbing materials. Moreover, the measurement errors for the analysis of the angular dependences of the reflected radiation are close to the errors of conventional ellipsometric measurement methods under fixed conditions, but they are much more informative and simpler in hardware design.
Based on measurements of the dependence of the reflection coefficient on the angle of incidence of monochromatic radiation, the possibilities of multiparameter, local, express, non-destructive determination of thickness, refractive indices and absorption of layers from a few nanometers to tenths of a micrometer are realized.

The obtained values for $\mathrm{n}, \mathrm{k}$, and $\mathrm{d}$ are located in ranges: for $\mathrm{n}-1.484$ and 1621 , for $\mathrm{k}-0.345$ and 0.062 , and for d- 136.20 and 74.66. To use carbon films as antireflection coatings, it is necessary that its refractive index has a value of about 2.0. However, those films with such refractive index can be used to form a homogeneous orientation of liquid crystals.

\section{REFERENCES}

[1] K. Enke, H. Dimigen, and H. Hubach, "Frictional properties of hard and insulating carbonaceous films grown in an R.F. discharge," Appl. Phys. Lett., vol. 36, no. 4, pp. 291-292, 1980.

[2] A. Bubenzer, B. Discler, G. Brandt, and P. Koidl, "Role of hard carbon in the field of infrared coating materials," J. Appl. Phys., vol. 54 , no. 8, pp. 4590-4595, 1983, DOI: $\underline{10.1117 / 12.7973404}$.

[3] K. Enke, "Hard carbon layer for wear protection and the antireflection purposes of infrared devices," Appl. Opt., vol. 24, pp. 508-512, 1985, PMID: 18216979.

[4] S. F. Pellicori, C. M. Peterson, and T. P. Henson, "Transparent carbon films: Comparison of properties between ion- and plasmadeposition processes," J. Vac. Sci. Technol. A, vol. 4, pp. 2350-2355, 1986, DOI: $\underline{10.1116 / 1.574075}$.

[5] L. Klibanov, N. I. Croitoru, A. Seidman, V. Gilo, and R. Dahan, "Diamond-like carbon thin films as antireflective and protective coatings of GaAs elements and devices," Opt. Eng., vol. 39, no. 4, pp. 989 - 992, 2000, DOI: 10.1117/1.602448.

[6] R. Memming, "Properties of a-C:H layers made by CVD," Thin Solid Films, vol. 143, pp. 279-289, 1986.

[7] E. A. Konshina, V. A. Tolmachev, A. I. Vangogen, and L. A. Fatkylina, "Investigation of the properties of plasma-polymerized layers and their influence on the orientation of nematic liquid crystals," Opt. journal., vol. 64, no. 5, pp. 88-95, 1997.

[8] V. A. Tolmachev and E. A. Konshina, "Ellipsometric study of a-C:H films," Diam. Relat. Mater., vol. 5, no. 12, pp. 1397-1401, 1996, DOI: $10.1016 / \mathrm{S} 0925-9635(96) 00551-1$.

[9] E. A. Konshina, V. A. Tolmachiev, A. I. Vangonen, and A. P. Onokhov, "Novel alignment layers produced by CVD technique from hydrocarbon plasma," Proc. SPIE, vol. 3015, pp. 52-60, 1997, DOI: $10.1117 / 12.271402$.

[10] R. M. A. Azzam and N. M. Bashara, Ellipsometry and polarized light. 1977. 
УДК 524.572

\title{
Особливості використання алмазоподібних вуглецевих плівок в якості антивідбивних покриттів
}

\author{
Зелінський ${ }^{\mathrm{f}}$ Д., ORCID 0000-0002-8617-6562 \\ Національний технічний університет України \\ "Київський політехнічний інститут імені Ігоря Сікорського" \\ Київ, Україна
}

Горохов B., н.с., ORCID 0000-0002-5609-6916

Інститут надтвердих матеріалів ім. В.М. Бакуля НАН України

Київ, Україна

Кондратенко О., к.т.н., ORCID 0000-0003-1948-4431

Інститут фізики напівпровідників ім. В.С. Лашкарьова НАН України Київ, Україна

Шмирьова ${ }^{\text {s Л., к.т.н. доц., ORCID 0000-0001-5497-4140 }}$

Національний технічний університет України

"Київський політехнічний інститут імені Ігоря Сікорського"

Київ, Україна

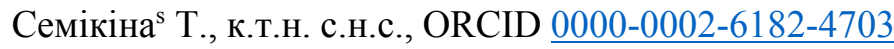

Інститут фізики напівпровідників ім. В.С. Лашкарьова НАН України Київ, Україна

Анотація-Плівки аморфного гідрогенізованого вуглецю а-С:Н завдяки таким властивостям, як хімічна інертність, інфрачервнева прозорість, твердість, зносостійкість, низький коефіціснт тертя та біосумісність знаходять застосування в оптиці і електроніці, машинобудуванні та медицині. В представленій роботі плівки аморфного вуглецю досліджуються з метою подальшого їх застосування в якості антивідбиваючого покриття на інфрачервневих вікнах з германію, а також для оріснтування рідких кристалічних шарів в рідкокристалічних модуляторах світла. В роботі наведено технологічні чинники плазмохімічного осадження плівок з газової фази як одного з найпоширеніших та результативних технологічних методів.

Серія 3 трьох алмазоподібних вуглецевих плівок була виготовлена за допомогою плазмохімічної установки для осадження а-C:H плівок. Осаджені плівки аналізували спектроскопічним еліпсометром Semilab SE-2000, що являє собою унікальну модульну оптичну платформу, що включас спектроскопічний еліпсометр з обертовим компенсатором. Спектральний еліпсометр дозволяє проводити безконтактний, неруйнівний оптичний аналіз одно- і багатошарових структур на кремнії, склі, плівковому носії, а також визначати товщину тонкоплівкових зразків і їх оптичні властивості такі як: коефіціснт заломлення, показник поглинання, оптична ширина забороненої зони. В роботі наведено залежності отриманих еліпсометричних коефіцієнтів. На основі отриманих залежностей було виконано розрахунки з використанням матриць та рівнянь Френеля.

На основі вимірювань залежності коефіціснта відбиття від кута падіння монохроматичного випромінювання реалізовані можливості багатопараметричного, локального, експрес-неруйнівного визначення товщини, показників заломлення та поглинання шарів від кількох нанометрів до десятих мікрометра. Отримані значення для $\mathrm{n}, \mathrm{k} \mathrm{i} d$ знаходяться в діапазонах: для $n$ - 1,448 - 1,621, для k - 0,345 - 0,062, а для d від 136,20 нм до 74,66 нм. Для використання вуглецевих плівок в якості антивідбивних покриттів необхідно, щоб його показник заломлення мав значення близько 2,0. Отримані значення показника заломлення с меншими, що не відповідає вимогам для антивідбивних покриттів. Але значення n - 1,448 - 1,621 задовольняє вимогам використання плівок для формування однорідної оріснтації рідких кристалів в пристроях на їх основі.

Ключові слова - плівка DLC; Метод РЕCVD; спектроскопічна еліпсометрія; антивідбивні покриття; показник заломлення. 